\title{
Fungal and Bacterial Pigments: Secondary Metabolites with Wide Applications
}

\author{
Manik Prabhu Narsing Rao ${ }^{1 \dagger}$, Min Xiao ${ }^{1 \dagger}$ and Wen-Jun $\mathrm{Li}^{1,2 *}$ \\ ${ }^{1}$ State Key Laboratory of Biocontrol and Guangdong Provincial Key Laboratory of Plant Resources, School of Life Sciences, \\ Sun Yat-sen University, Guangzhou, China, ${ }^{2}$ Key Laboratory of Biogeography and Bioresource in Arid Land, Xinjiang Institute \\ of Ecology and Geography, Chinese Academy of Sciences, Ûrúmqi, China
}

OPEN ACCESS

Edited by:

Peter Neubauer,

Technische Universität Berlin,

Germany

Reviewed by:

Antti IImari Vasala,

BioSilta Oy, Finland

Michael Craig Crampton,

Council for Scientific and Industrial

Research, South Africa

*Correspondence:

Wen-Jun Li

liwenjun3@mail.sysu.edu.cn;

liact@hotmail.com

†These authors have contributed equally to this work.

Specialty section:

This article was submitted to Microbiotechnology, Ecotoxicology and Bioremediation,

a section of the journal

Frontiers in Microbiology

Received: 23 December 2016

Accepted: 31 May 2017

Published: 22 June 2017

Citation:

Narsing Rao MP, Xiao M and Li W-J (2017) Fungal and Bacterial Pigments:

Secondary Metabolites with Wide

Applications.

Front. Microbiol. 8:1113.

doi: 10.3389/fmicb.2017.01113
The demand for natural colors is increasing day by day due to harmful effects of some synthetic dyes. Bacterial and fungal pigments provide a readily available alternative source of naturally derived pigments. In contrast to other natural pigments, they have enormous advantages including rapid growth, easy processing, and independence of weather conditions. Apart from colorant, bacterial and fungal pigments possess many biological properties such as antioxidant, antimicrobial and anticancer activity. This review outlines different types of pigments. It lists some bacterial and fungal pigments and current bacterial and fungal pigment status and challenges. It also focuses on possible fungal and bacterial pigment applications.

Keywords: color, pigments, synthetic dye, microbial pigments, secondary metabolites

\section{INTRODUCTION}

Color affects every bit of life, including the clothes we wear, the furniture in our home, and the allure of food (Downham and Collins, 2000; Manikprabhu and Lingappa, 2013). Just think, for instance, how plants could prepare their own food without chlorophyll or how oxygen could be carried in the body without hemoglobin. It can be said that life on earth depends on pigments (Britton, 1995).

The use of pigments as coloring agents has been practiced since prehistoric times. Archaeologists have uncovered evidence that early humans used paint for aesthetic purposes. The use of pigment in prehistoric times was further proven when pigments and grinding equipments, which were between 350,000 and 400,000 years old, were found in a cave at Twin Rivers, near Lusaka, Zambia (Kassinger, 2003). Pigments were used in different parts of the world. In Europe, it was practiced during the Bronze Age. In China, dyeing with plants, barks, and insects has been traced back more than 5,000 years. In India, it occurred during the Indus Valley period (2500 BC) (Gokhale et al., 2004; Aberoumand, 2011). Henna was used before 2500 BC, while saffron has been mentioned in the Bible (Gulrajani, 2001). In Egypt, mummies have been found wrapped in colored cloth, which showed the presence of alizarin.

The addition of color to food started in Egypt when candy makers added natural extracts to their candy. Similarly, the use of natural colorants in food was seen in Japan in the shosoin text of the Nara period (8th century) that contains references to coloring soybean and adzuki-bean cakes (Aberoumand, 2011).

The first synthetic color, mauvine, was developed by Sir William Henry Perkin in 1856 and this development started a revolution in the history of synthetic colorants (Walford, 1980). 
Since then, the synthetic color industrial revolution has rapidly proceeded (Downham and Collins, 2000). Synthetic color captured the market due to ease of production, less expensive, no unwanted flavors imparted to food, superior coloring properties, and only tiny amounts are needed to color anything. Sellers at the time offered more than 80 artificial coloring agents. Many color additives at that time had never been tested for their toxicity or other adverse effects, which ultimately led to adverse effects on the health and environment (Downham and Collins, 2000).

Dyes such as tartrazine, cochineal red, and sunset yellow provoke allergies either on their own or in combination with other colorants. Although, some synthetic colorants that had been approved by the Food and Drug Administration (FDA) for use in foods, pharmaceuticals, and cosmetic preparations were later found to promote cancer. Some synthetic dyes have even been withdrawn from external use due to their apparent hazards. For example, benzidine dyes cause bowel cancer, while carbon black (widely used as printing ink pigment) is thought to be a potential carcinogen. From the environmental point of view, unethical discharge of untreated industrial dye effluents produce toxins and persist for long time due to long periods of stability (Babitha, 2009). The drawbacks of synthetic color have increased the global demand for natural pigments (Manikprabhu and Lingappa, 2013).

The main sources for natural pigments are plants or microorganisms. The use of plant pigments has many drawbacks such as non-availability throughout the year and pigment stability and solubility. Large scale plant use may lead to loss of valuable species. For these reasons, the process may not consider viable (Downham and Collins). Microorganisms such as fungi and bacteria provide a readily available alternate source of naturally derived pigments (Arulselvi et al., 2014). Bacterial and fungal pigments have extensive applications (Table 1) and have an enormous advantage over plant pigments, including easy and rapid growth in low cost medium, easy processing, and growth that is independent of weather conditions (Manikprabhu and Lingappa, 2013).

\section{Market Trend}

There are no reliable published statistics on the size of the color market (Babitha, 2009); however, according to global industry analysts, the demand for organic pigments and dyes is expected to reach almost 10 million tons by 2017. Among the various available pigments, the carotenoids alone are estimated to reach $\$ 1.4$ billion by 2018 (Venil et al., 2014).

Microbial production of $\beta$-carotene costs approximately US $\$ 1000 / \mathrm{kg}$ versusUS $\$ 500 / \mathrm{kg}$ for synthetic means. Though microbial pigments are several times more expensive, they still can compete with synthetic dyes for being natural and safe (Venil et al., 2013). There is an increased push to reduce the production costs for microbial pigments by using low cost substrates or strain improvements, and in the near future, there may be a monopoly market for microbial pigments.

Textile industries remains the largest consumer of organic pigments and dyes, while faster growth is expected to occur in other industrial sector such as printing inks, paints, and coating agents. The value of the international food colorant market, which was estimated at around \$1.15 billion USD in 2007 (Mapari et al., 2010), may also increase in the future due to food coloring approval for use in the food industry (Aberoumand, 2011).

\section{Fungal Pigments}

Filamentous fungi are known to produce an extraordinary range of pigments such as carotenoids, melanins, flavins, phenazines, quinones, monascins, violacein, and indigo (Dufosse et al., 2014). The use of Monascus for ang-kak (red mold rice) production is the oldest recorded use of fungal pigment. Monascus produce yellow (ankaflavine, monascine), orange (rubropunctatine, monascorubrine), and purple (rubropunctamine, monascorubramine) pigments which are often encountered in Oriental foods, especially in Southern China, Japan and Southeast Asia. Currently, more than 50 Monascus pigments have been identified and studied. More than 50 patents around the globe have been issued concerning the use of Monascus pigments in food (Dufosse et al., 2005). Monascus pigments possess antimicrobial, anticancer, anti-mutagenic, and anti-obesity properties (Feng et al., 2012).

There are more than 200 fungal species reported for carotenes production (Dufosse et al., 2005). Carotenes production was often found in zygomycetes from the order Mucorales, which includes Phycomyces, Blakeslea, and Mucor. In addition to Mucorales, carotene production has been reported in the basidiomycetes genera such as Rhodosporidium, Sclerotium, Sclerotinia, Sporidiobolus, and Ustilago. Ascomycetes such as Aspergillus, Cercospora, Penicillium, and Aschersonia have also been reported for carotenes production (Avalos and Carmen Limon, 2015).

Pigments such as anthraquinones, naphthaquinones, dihydroxy naphthalene melanin, flavin, anthraquinone, chrysophanol, cynodontin, helminthosporin, tritisporin, and erythroglaucin were reported by genera such as Eurotium, Fusarium Curvularia and Drechslera (Babitha, 2009).

Recent literature extensively has reported the interest in marine organisms with respect to the production of new molecules, including new pigments. Indeed, many marine ecological niches are still unexplored. Marine environments have unique features such as low temperatures, absence of light and high pressure and salinity. These conditions induce marine microorganisms to produce unique substances (Dufosse et al., 2014). Genera such as Aspergillus (He et al., 2012), Penicillium (Dhale and Vijay Raj, 2009), Trichoderma (Blaszczyk et al., 2014), and Eurotium (Smetanina et al., 2007) have been reported for pigment production. Marine derived fungal pigments are quite similar to terrestrial derived fungal pigments (Capon et al., 2007); however, some pigments were obtained only from marine fungi. Yellow pigment (anthracene-glycoside asperflavinribofuranoside) produced by Microsporum sp. appears only in marine-derived fungus (Li et al., 2006).

Several marine-derived endophytic fungi such as Eurotium rubrum (Li et al., 2009), Halorosellinia (Xia et al., 2007), Hortaea, Phaeotheca, and Trimmatostroma have been reported for pigment production (Dufosse et al., 2014). Apart from plants, marine fungi also make associations with algae and corals. Reports suggest that marine endophytic fungi produce pigments 
TABLE 1 | Fungal and bacterial pigments and their applications.

\begin{tabular}{|c|c|c|c|}
\hline Fungi/Bacteria & Pigment & Application & Reference \\
\hline \multicolumn{4}{|l|}{ Bacteria } \\
\hline Micromonospora lupine & Anthraquinone & Antitumor agent & Igarashi et al., 2007 \\
\hline Streptomyces sp. & Carotenoid & Food-grade pigment & Dharmaraj et al., 2009 \\
\hline Chromobacterium & Violacein & Anti-tumor, anti-microbial, and anti-parasitic agent & Duran et al., 2007 \\
\hline Chromobacterium sp. NIIST (MTCC 5522) & Violacein & Antifungal agent & Sasidharan et al., 2015 \\
\hline Hymenobacter sp. and Chryseobacterium sp. & Carotenoid & Photo-sensitizers in dye sensitized solar cells & Ordenes Aenishanslins et al., 2016 \\
\hline Streptomyces glaucescens NEAE-H & Melanin & Anti-cancer agent and anti-oxidant & El-Naggar and El-Ewasy, 2017 \\
\hline Pseudomonas aeruginosa & Pyocyanin & Anti-microbial agent & El-Fouly et al., 2015 \\
\hline Hahella chejuensis & Prodiginines & Antibiotic & Kim et al., 2007 \\
\hline Pedobacter & Carotenoid & Antioxidant & Correa Llanten et al., 2012 \\
\hline Vogesella indigofera & Blue pigment & Detect heavy metal & Gu and Cheung, 2001 \\
\hline \multicolumn{4}{|l|}{ Fungi } \\
\hline Aspergillus versicolor & Asperversin & Antifungal agent & Miao et al., 2012 \\
\hline Fusarium sp. JN158 & Benzoquinon & Anticancer agent & Zheng et al., 2017 \\
\hline Fusarium oxysporum & Anthraquinone & Dyeing of wool fabrics & Nagia and El-Mohamedy, 2007 \\
\hline Talaromyces verruculosus & Red pigment & Dye textile having antimicrobial activity & Chadni et al., 2017 \\
\hline Stemphylium lycopersici & Anthraquinone & Antioxidant & Li et al., 2017 \\
\hline
\end{tabular}

that help to mimic and often increase the beauty of the associated life form (Dufosse et al., 2014). Fungus like Aspergillus associates with coral skeleton (Porites lutea and Porites lobata) and imparts black bands that are quite similar to the coral color (Priess et al., 2000).

Although several fungal pigments have been reported in the literature, they must satisfy several criteria regarding their toxicity, regulatory approval, stability, and capital investment required to bring the products from Petri dish to the market (Malik et al., 2012). Although used for centuries, many microbial pigments are still forbidden in many countries. The best example is the Monascus pigment that has been used in Asia for centuries as a food colorant but forbidden in Europe and United States due to the presence of mycotoxin (Dufosse et al., 2005). In this context, methods were developed to avoid toxin productions.

(a) Selection of non-pathogenic strains: to evaluate whether toxin production was strain specific, several strains were screened to check toxicity. The toxin production was observed only in some strains, indicating the toxin production was strain specific.

(b) Through controlling the biosynthesis of the metabolite: toxin production can be controlled through the biosynthesis process; this can be achieved when the metabolic pathway were investigated.

(c) Media selection: researcher observed that the addition or removal of metal ions, carbon sources, and nitrogen sources can affect toxin production (Hajjaj et al., 2000; Dufosse et al., 2005); hence, selection of media plays a crucial role in controlling the toxin production.

Apart from toxin production, microbial pigments should withstand extreme $\mathrm{pH}$ and temperature in order to meet industrial standards. Many fungal pigments are stable at a wide $\mathrm{pH}$ range.
Pigments produced by Monascus purpureus, Isaria farinosa, Emericella nidulans, Fusarium verticillioides, and Penicillium purpurogenum showed improved dyeing ability at acidic $\mathrm{pH}(\mathrm{pH}$ 5) (Velmurugan et al., 2010). Pigment produced by Thermomyces was stable from acidic to moderate alkaline conditions ( $\mathrm{pH} 5.1$ and 8.0) (Poorniammal and Gunasekaran, 2015). The pigment produced by Penicillium aculeatum which is used in soft drink found stable at neutral pH (Mapari et al., 2009). The pigment produced by Monascus purpureus was stable even at high alkaline conditions (pH 11) (Huang et al., 2011).

Fungal pigments are stable at various temperatures. Pigments from Monascus purpureus, Isaria spp., Emericella spp., Fusarium spp., and Penicillium spp. used for the dyeing pre-tanned leather samples that were found stable at high temperatures (Velmurugan et al., 2010). Monascus pigment when added to sausages showed $92 \%$ to $98 \%$ stability at $4{ }^{\circ} \mathrm{C}$ for three months (Fabre et al., 1993).

Though many fungi were reported for non-toxic and stable pigments production, but the development of fermentation derived pigments needs high capital investment in terms of media components. The best example is microbial production of $\beta$-carotene. The microbial production of $\beta$-carotene cost approximately US $\$ 1000 / \mathrm{kg}$ versus US $\$ 500 / \mathrm{kg}$ produced by synthetic means (Venil et al., 2014).

To counter balance the production cost, researchers have shown a great interest in the use of waste or industrial sidestreams for the fermentation processes in the development microbial pigments (Panesar et al., 2015). Many fungi were reported for pigment production in low cost substrate. Monascus ruber reported for pigment production utilizing corn steep liquor as a nitrogen source instead of yeast extract (Hamano and Kilikian, 2006). Similarly, Monascus purpureus produce pigment using grape waste (Silveira et al., 2008). Despite many hurdles, fungal pigments made their way to the market and compete with synthetic colors. Food grade pigments from fungi, including 
TABLE 2 | Fungal and bacterial pigments studied or applied for commercial production.

\begin{tabular}{|c|c|c|c|}
\hline Fungi/Bacteria & Color & Pigment & Status \\
\hline \multicolumn{4}{|l|}{ Fungi } \\
\hline Monascus spp. & Yellow & Ankaflavin & Industrial production $\#$ \\
\hline Monascus spp. & Orange & Rubropunctatin & Industrial production \# \\
\hline Ashbya gossip & Yellow & Riboflavin & Industrial production $\#$ \\
\hline Cordyceps unilateralis & Deep blood red & Naphtoquinone & Industrial production $\#$ \\
\hline Monascus spp. & Red & Monascorubramin & Industrial production $\#$ \\
\hline Penicillium oxalicum & Red & Anthraquinone & Industrial production $\#$ \\
\hline Blakeslea trispora & Red & Lycopene & Development stage** \\
\hline Blakeslea trispora & Yellow-orange & B-carotene & Industrial production** \\
\hline Mucor circinelloides & Yellow-orange & B-carotene & Development stage** \\
\hline \multicolumn{4}{|l|}{ Bacteria } \\
\hline Bradyrhizobium spp. & Orange & Canthaxanthin & Research project ${ }^{\#}$ \\
\hline Streptomyces sp. & Yellow & Carotenoids & Development stage* \\
\hline Streptomyces echinoruber & Red & Rubrolone & Development stage** \\
\hline Paracoccus zeaxanthinifaciens & Yellow & Zeaxanthin & Research project** \\
\hline Paracoccus carotinifaciens & Pink-red & Astaxhantin & Research project** \\
\hline Bradyrhizobium sp. & Dark-red & Canthaxhantin & Research project** \\
\hline Pseudomonas spp. & Blue, green & Pyocyanin & Industrial production $\#$ \\
\hline Flavobacterium spp. & Yellow & Zeaxanthin & Development stage ${ }^{\#}$ \\
\hline Agrobacterium aurantiacum & Pink-red & Astaxanthin & Research project ${ }^{\#}$ \\
\hline
\end{tabular}

Data obtained from \#Tuli et al., 2015; *Venil et al., 2013; ** Ahmad et al., 2012.

Monascus pigments, Arpink red ${ }^{\mathrm{TM}}$ from Penicillium oxalicum, riboflavin from Ashbya gossypii, lycopene, and $\beta$-carotene from Blakeslea trispora are now available in the market (Dufosse et al., 2014). Many fungal pigments are already used for industrial production, while some are in the development stage (Table 2).

\section{Bacterial Pigments}

The use of bacteria for pigment production has several advantages over fungi, such as short life cycle and ease for genetic modification (Venil et al., 2013, 2014). However, compared with fungal pigments, most of bacterial pigments are still at the research and development stage (Table 2); hence, work on bacterial pigments production should be intensified to make them available on the market. Pigment producing bacteria are ubiquitous and present in various ecological niches, such as soil (Zhu et al., 2007), rhizospheric soil (Peix et al., 2005), desert sand (Liu et al., 2009), fresh water (Asker et al., 2008), and marine samples (Franks et al., 2005). They were reported in low (Nakamura et al., 2003) and high (Manachini et al., 1985) temperature regions, can persist in salt regions (Asker and Ohta, 1999), and even as endophytes (Deng et al., 2011).

Compared with other bacterial groups, the pigment production is more likely to be present in actinobacteria (Marroquin and Zapata, 1954). Various genera such as Streptomyces, Nocardia, Micromonospora, Thermomonospora, Actinoplanes, Microbispora, Streptosporangium, Actinomadura, Rhodococcus, and Kitasatospora (Rana and Salam, 2014) produce a wide variety of pigments. The genus Streptomyces was reported for highest pigment production (Conn and Jean, 1941). Many species of this genus, like Streptomyces griseus, Streptomyces griseoviridis, Streptomyces coelicolor (Darshan and Manonmani, 2015), Streptomyces cyaneus (Petinate et al.,
1999), Streptomyces vietnamensis (Zhu et al., 2007), Streptomyces peucetius (Arcamone, 1998), Streptomyces echinoruber (Gupta et al., 2011), Streptomyces shaanxiensis (Lin et al., 2012), and Streptomyces caeruleatus (Zhu et al., 2011) were reported to produce pigments.

Similar to fungi, bacteria also produce a wide range of pigments such as carotenoids, melanin, violacein, prodigiosin, pyocyanin, actinorhodin, and zeaxanthin (Ahmad et al., 2012; Venil et al., 2014).

Two fundamental biotechnological approaches are applied when producing microbial pigments; firstly a search for new sources, and secondly enhancing the yield of already recognized sources either through optimization or strain improvement (Venil et al., 2013). To obtain new sources, several ecological niches were screened, and many pigments producing novel bacterial strains (Table 3) were discovered suggesting their vast availability. Strain improvement through chemical and physical mutations significantly varied the pigment production. Strain improvement through ultraviolet (UV) mutation increased prodigiosin production by 2.8 -fold when compared with the parent strain (Tao et al., 2005). Employment of UV radiation and ethyl methanesulfonate enhanced pigment production in Serratia marcescens (El-Bialy and Abou El-Nour, 2015). Cultural conditions and media optimization showed increased pigment production. Bacillus sp. showed significant pigment production when cultivated at $\mathrm{pH} 7.0 \pm 0.1$ and a temperature of $34^{\circ} \mathrm{C}$ (Mondal et al., 2015). Similarly, Duganella sp. B2 under optimum $\mathrm{pH}$ and nitrogen sources showed increased violacein (4.8-folds) production (Wang et al., 2009).

Recent developments in genetic engineering have made it now possible to modify the bacteria to produce the pigment of interest. Streptomyces coelicolor, which produces a blue pigment, can be 
TABLE 3 | List of novel bacteria producing pigments.

\begin{tabular}{|c|c|c|c|c|}
\hline Bacteria & Gram & Pigment & Isolated from & Reference \\
\hline Paracoccus haeundaensis & Positive & Orange & Sea water & Lee et al., 2004 \\
\hline Streptomyces vietnamensis & Positive & Violet-blue & Soil & Zhu et al., 2007 \\
\hline Streptomyces shaanxiensis & Positive & Blue & Sewage irrigation soil & Lin et al., 2012 \\
\hline Streptomyces caeruleatus & Positive & Dark blue & Tomato rhizosphere soil & Zhu et al., 2011 \\
\hline Pseudomonas brassicacearumsubsp. neoaurantiaca & Negative & Red-orange & Rhizosphere & Ivanova et al., 2009 \\
\hline Pseudomonas argentinensis & Negative & Yellow & Rhizospheric soil & Peix et al., 2005 \\
\hline Bacillus nakamurai & Positive & Black & Soil & Dunlap et al., 2016 \\
\hline Nubsella zeaxanthinifaciens & Negative & Yellow & Freshwater & Asker et al., 2008 \\
\hline Kineococcus xinjiangensis & Positive & Brown & Desert sand & Liu et al., 2009 \\
\hline
\end{tabular}

genetically modified to produce a bright yellow (kalafungin), orange, or yellow-red (anthraquinones) pigment (Bartel et al., 1990; McDaniel et al., 1993).

\section{TYPES OF PIGMENTS}

\section{Carotenoids}

Carotenoids were first isolated by Heinrich Wilhelm Ferdinand Wackenroder (Wackenroder, 1831). All carotenoids are tetraterpenoids (Kocher and Muller, 2011) and there are over 600 known carotenoids, which are divided into two classes: xanthophylls (which contain oxygen) and carotenes (which are purely hydrocarbons, and contain no oxygen). Among the various carotenoids, the most important carotenoids (Figure 1) are alpha and beta-carotenes, cryptoxanthin, lutein, lycopene, violaxanthin, neoxanthin, zeaxanthin, and canthxanthin (Rymbai et al., 2011).

Commercial carotenoids are either extracted from vegetables or produced through chemical synthesis. Extraction of carotenoids from plants has many drawbacks such as seasonal and geographic variability while chemical synthesis generates hazardous wastes that can affect the environment. In contrast to these methods, the microbial production of carotenoids shows great praise for use of low-cost substrates and safety (Mata Gomez et al., 2014). Microorganisms producing carotenoids are many and include Flavobacterium multivorum (Bhosale and Bernstein, 2004), Rhodobacter sphaeroides (Chen et al., 2006), Rhodotorula mucilaginosa (Aksu and Eren, 2005), Sphingomonas sp. (Silva et al., 2004), Dunaliella sp., Blakeslea trispora, Phycomyces blakesleeanus, Mucor circinelloides, Fusarium sporotrichioides, Agrobacterium aurantiacum, Paracoccus carotinifaciens, Gordonia jacobea (Dufosse, 2006), Sporidobolus salmoncolor, Rhodosporium paludigenum, and Rhodotorula glutinis (Panesar et al., 2015).

Carotenoids producing microorganisms are diverse, isolated from soil (Arulselvi et al., 2014), cave (Liu et al., 2015), marine (Lee et al., 2004), and slattern crystallizer pond (Anton et al., 2002) environments.

The most prominent function of carotenoids is their contribution to harvest light energy. They absorb light and pass the excitation energy onto chlorophyll, thereby extending the wavelength range of harvested light (Kocher and Muller, 2011).
They protect chlorophyll from photo damage (Armstrong and Hearst, 1996). They are used as vitamin supplements and play an important role in protection from oxidative stress. Their intake can prevent photo-aging and sun burn (Della Penna and Pogson, 2006). Epidemiological studies have shown that people with high $\beta$-carotene intake have a reduced risk of lung cancer (Alija et al., 2004). Carotenoids are used commercially as food colorants, as animal feed supplements, and treatment for obesity. More recently they have been used for nutraceutical, cosmetic, and pharmaceutical purposes (Garrido-Fernandez et al., 2010; Jaswir et al., 2011).

\section{Melanin}

Melanins are indolic polymers (Surwase et al., 2013) classified as eumelanins, pheomelanins, and allomelanins (Banerjee et al., 2014). Melanin is commonly found in all living systems, and their presence in almost every large taxon suggests evolutionary importance (Plonka and Grabacka, 2006).

Melanin production has been reported by a wide variety of microorganisms such as Colletotrichum lagenarium, Magnaporthe grisea, Cryptococcus neoformans, Paracoccidioides brasiliensis, Sporothrix schenckii, Aspergillus fumigates (Langfelder et al., 2003), Vibrio cholerae, Shewanella colwelliana, Alteromonas nigrifaciens (Soliev et al., 2011), and many species of the genus Streptomyces (Manivasagan et al., 2013).

Melanin confers resistance to UV light by absorbing a broad range of the electromagnetic spectrum and preventing photoinduced damage (Hill, 1992). Melanin is used for mimicry, and protects against high temperatures and chemical stresses. Melanin is extensively used in cosmetics, photo protective creams, eyeglasses, and immobilization of radioactive waste such as uranium. Bacterial melanin genes have been used as reporter genes to screen recombinant bacterial strains. It has antiHIV properties and is useful for photo voltage generation and fluorescence studies. Melanin is also used to generate monoclonal antibodies for the treatment of human metastatic melanoma (Plonka and Grabacka, 2006; Surwase et al., 2013).

\section{Prodigiosin}

Prodigiosin (Figure 2) is a red pigment, first isolated from Serratia marcescens (Boger and Patel, 1987).

The name prodigiosin has been attributed to isolation from Bacillus prodigiosus which was later renamed as Serratia 


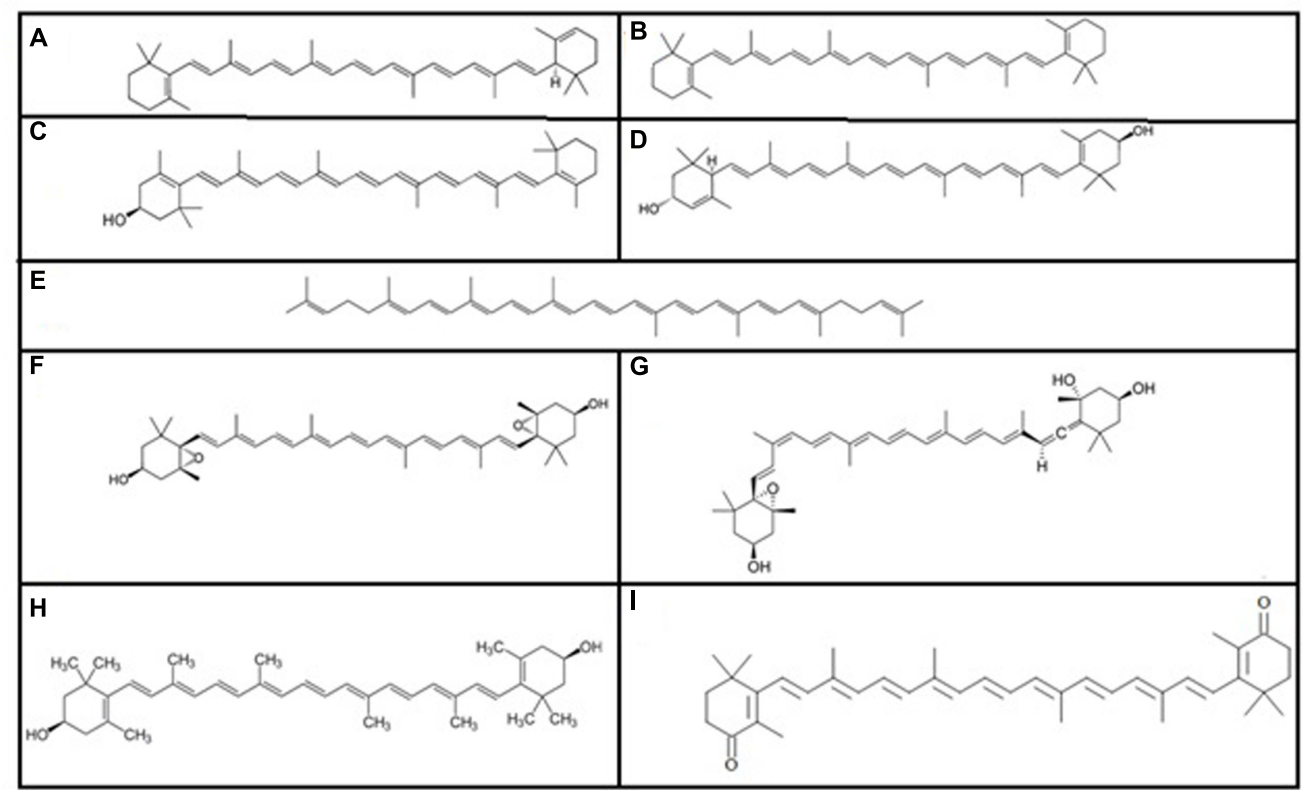

FIGURE 1 | Some important carotenoids: (A) alpha carotene, (B) beta-carotene, (C) cryptoxanthin, (D) lutein, (E) lycopene, (F) violaxanthin, (G) neoxanthin, (H) zeaxanthin, and (I) canthxanthin.

marcescens (Gerber, 1975). Apart from Serratia marcescens, prodigiosin production has been reported from Pseudomonas magneslorubra, Vibrio psychroerythrous, Vibrio gazogenes, Alteromonas rubra, Rugamonas rubra, and Streptoverticillium rubrireticuli (Darshan and Manonmani, 2015). Prodigiosin producing microbes are wide spread, and they are isolated from marine samples (Gandhi et al., 1976; Kim et al., 2007), shallow estuarine water (Boric et al., 2011), tidal flat sediment (Yi et al., 2003), and beach sand (Ramaprasad et al., 2015). Prodigiosin acts as a potent therapeutic molecule, especially as

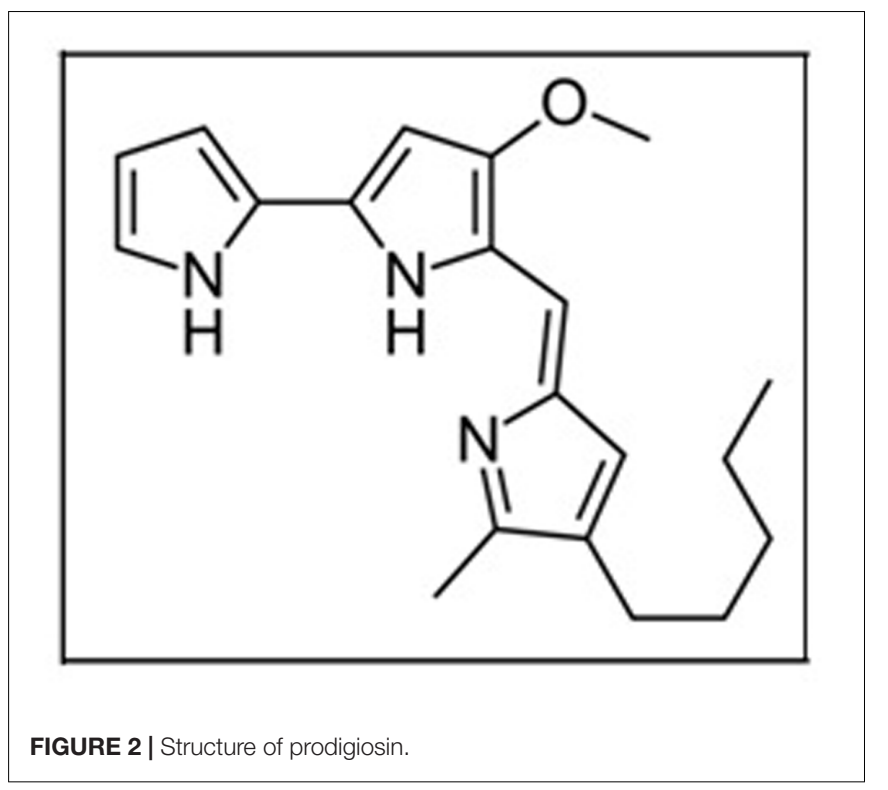

an immuno-suppresser and anticancer agents. Prodigiosin also shows insecticidal, antifungal, antibacterial, and anti-malarial activities (Harris et al., 2004; Kamble and Hiwarale, 2012).

\section{Violacein}

Violacein is a violet colored pigment, first described from Gram-negative bacterium Chromobacterium violaceum isolated from Amazon River in Brazil. Apart from Chromobacterium violaceum, violacein production has been reported from various microorganisms such as Collimonas sp., Duganella sp., Janthinobacterium lividum, Microbulbifer sp., Pseudoalteromonas luteoviolacea, Pseudoalteromonas tunicata, and Pseudoalteromonas ulvae inhabiting different environments like soil, marine (Yada et al., 2008; Aranda et al., 2011), glacier (Lu et al., 2009), sea surface (Hakvag et al., 2009), rhizosphere (Aranda et al., 2011), and surface of marine sponge (Yang et al., 2007).

Violacein has been reported for variety of biological activities including antiviral, antibacterial, antiulcerogenic, antileishmanial, anticancer, and enzyme modulation properties (Matz et al., 2004; Duran et al., 2007; Soliev et al., 2011)

\section{Riboflavin}

Riboflavin (Figure 3), also called vitamin $\mathrm{B}_{2}$ is water soluble pigment that exhibits a strong yellowish-green fluorescence. It was first isolated by the English chemist Alexander Wynter Blyth (Blyth, 1879). The riboflavin structure was confirmed by Kuhn and Weygand, which suggests that it has two distinct parts consisting of a ribose sugar unit and a three-ring flavin structure known as a lumichrome (Kuhn et al., 1933). Riboflavin is an essential vitamin that needs to be supplemented in the human 


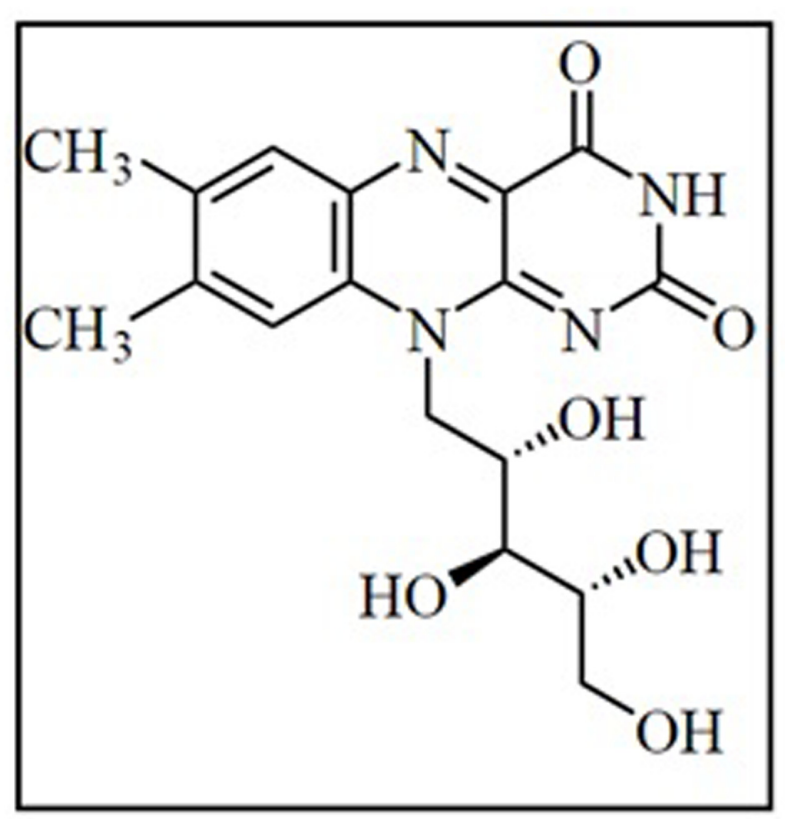

FIGURE 3 | Structure of riboflavin

diet at a concentration of 1.1-1.3 mg per day. Riboflavin acts as a structural component of the coenzymes flavin mononucleotide and flavin adenine dinucleotide. Both coenzymes catalyze non-enzymatic oxidation-reduction reactions by functioning as dehydrogenating hydrogen carriers in the transport system involved in ATP production. For over 30 years, riboflavin supplements have been used as part of the phototherapy treatment for neonatal jaundice. Riboflavin co-treatment with $\beta$ blockers showed improvement against migraine headaches (Kutsal and Ozbas, 1989; Feroz, 2010). Riboflavin in combination with UV light has been shown to be effective in reducing harmful pathogens found in blood products (Goodrich et al., 2006).

\section{Pyocyanin}

Pyocyanin (Figure 4) is a blue pigment produced by Pseudomonas aeruginosa (Hassan and Fridovich, 1980). It is composed of two subunits of $N$-methyl-1-hydroxyphenazine (Norman et al., 2004). To synthesize pyocyanin, specific genes must be functional. $M v f R$ is a gene which produces a transcription factor which activates $p h n A B$ genes. These genes produce the molecule quinolone which then regulates operons 1 and 2 of phzRABCDEFG which are the key to the synthesis pyocyanin (Mavrodi et al., 2001). Pyocyanin has been used as bio-control agent and possess anti-bacterial and anti-fungal activity (Jayaseelan et al., 2014).

\section{APPLICATIONS OF PIGMENTS Pigments in Textile Industry}

The textile industry uses approximately 1.3 million tons of synthetic dyes and dye precursors (Venil et al., 2013). About 200,000 tons of dyes are lost as effluents every year during the

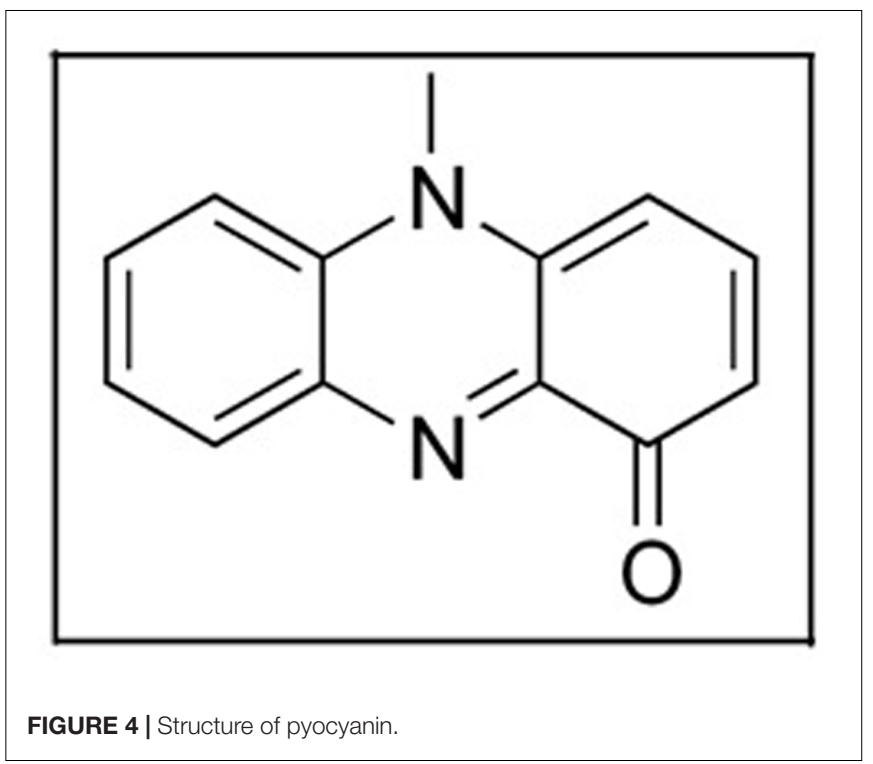

dyeing and finishing operations. Unfortunately, most of these dyes escape conventional wastewater treatment processes and persist in the environment as a result of their high stability against light, temperatures, water, detergents, chemicals, soap, and other parameters such as bleach and perspiration (Ogugbue and Sawidis, 2011). In this context, there is a great concern about using eco-friendly dyes. Microbial pigments are eco-friendly colorants applicable to dyeing textile fabrics (Chadni et al., 2017). Many microbial pigments were used to dye different types of fabric. Prodigiosin from Vibrio spp. can dye wool, nylon, acrylics, and silk. By using tamarind as a mordant, pigment from Serratia marcescens can color up to five types of fabric, including acrylic, polyester microfiber, polyester, silk, and cotton (Yusof, 2008). Anthraquinone from Fusarium oxysporum can be used to dye wool fabrics (Nagia and El-Mohamedy, 2007). Recently, Sudha, Gupta and Aggarwal (2016) reported dyeing of wet blue goat nappa skin with the Penicillium minioluteum pigment. A red pigment from Talaromyces verruculosus shows an adequate color tone for cotton fabric without any cytotoxic effect (Chadni et al., 2017).

Microbial pigments produce different color tones in different textiles. Pigment from Janthinobacterium lividum show a bluishpurple color tone on silk, cotton, and wool, while dark blue is seen with nylon and vinylon (Shirata et al., 2000). Similarly, the dyeing ability of yellow pigment from Thermomyces was evaluated for cotton, silk, and wool fabrics. It was observed that silk fabric showed high affinity for Thermomyces pigments when compared with other fabrics (Poorniammal et al., 2013). Deep blue and red pigments from Streptomyces strains NP2 and NP4 also showed significant changes in dyeing ability with respect to the material used. Polyamide and acrylic fibers were stained vibrantly, while cotton and cellulosic fibers were stained weakly (Kramar et al., 2014).

In addition, as a colorant, microbial dyed textiles, showed antimicrobial properties. Textile fabric dyed by prodiginines obtained from Vibrio sp. showed antibacterial activity against 
Staphylococcus aureus and Escherichia coli (Alihosseini et al., 2008). In the view of the extensive availability of the microbial pigments, their affinity towards different textiles, cost effectiveness, and nontoxic nature, microbial pigments may increase their market appeal and could replace such synthetic colors which are toxic to mankind and nature.

\section{Pigments as Antimicrobial Agents}

The increasing emergence of multidrug resistant bacteria worldwide and the lack of antibiotics to combat such pathogens continue to be a major concern for the medical community (Manikprabhu and Li, 2015). Microbial pigments serve as antimicrobial agents against a wide range of pathogens. Pigments such as carotenoids, melanins, flavins, quinones, monascins, violacein, and indigo have been reported as good antimicrobial agents (Malik et al., 2012). Pigments such as pyocyanin and pyorubin obtained from Pseudomonas aeruginosa have shown distinct antibacterial activity against Citrobacter sp., which are usually associated with urinary tract and wound infections. Pigments produced from Micrococcus luteus KF532949 showed promising antimicrobial activity against wound associated pathogens such as Staphylococcus sp., Klebsiella sp., and Pseudomonas sp. (Umadevi and Krishnaveni, 2013). Pigment obtained from Streptomyces hygroscopicus, even showed good antimicrobial activity against drug resistant pathogens such as methicillin and vancomycin resistant strains of Staphylococcus aureus and $\beta$-lactamase producing strains of Escherichia coli, Pseudomonas aeruginosa, and Klebsiella sp. (Berlanga et al., 2000; Selvameenal et al., 2009). Pigment from Monascus ruber showed antimicrobial activity against food borne bacteria (Vendruscolo et al., 2014). Further, inhibition of human pathogenic bacteria such as Staphylococcus aureus, Klebsiella pneumoniae, and Vibrio cholera was observed by the pigment of an endophytic fungal species Monodictys castaneae (Visalakchi and Muthumary, 2010).

Efforts in understanding the mechanism of antibacterial activity of some pigments have also been made. The mode of antibacterial action of prodigiosin produced from Vibrio sp. DSM 14379 against Escherichia coli was evaluated. It was found that the prodigiosin treated Escherichia coli cells showed membrane leakage, decreased respiration, and inhibition of protein and RNA synthesis (Danevcic et al., 2016). In view of the above, microbial pigments apart from coloring agents, can be used as novel drugs.

\section{Pigments as Food Colorants}

The development of foods with an attractive appearance is an important goal in the food industry. To make the food appealing, either synthetic or natural colors are added. In recent days, food producers are turning from synthetic to natural colors, due to negative health issues associated with some synthetic colors (Aberoumand, 2011; Venil et al., 2013). Natural colorants from microbes play a significant role as food coloring agents, because of its cheap production, easier extraction, high yield, and no lack of raw materials and seasonal variations (Malik et al., 2012). Many pigments from microbial sources such as red pigment from Monascus sp., astaxanthin from Xanthophyllomyces dendrorhous, Arpink red ${ }^{\mathrm{TM}}$ from Penicillium oxalicum, riboflavin from Ashbya gossypii, $\beta$-carotene from Blakeslea trispora, and lycopene from
Erwinia uredovora and Fusarium sporotrichioides were added to the food to increase its appeal (Dharmaraj et al., 2009). Pigment like canthaxanthin used in foods, particularly in products such as cheese, candy, fish, meat, fruits, beverages, snacks, beer, and wine. Pigments like riboflavin (i.e., vitamin B2) are used in beverages, instant desserts and ice creams. Carotenoids can act as a sunscreen to maintain the quality of food by protecting them from intense light (Chattopadhyay et al., 2008).

\section{Pigments as Antioxidants}

An increase in free radicals in the body enhances the chances of occurrence of chronic diseases such as cancer, diabetes, cardiovascular, and autoimmune disorders (Rankovic et al., 2011). To avoid this, antioxidants are used. Antioxidants are molecules that delay or inhibit cellular damage by donating electrons to a rampaging free radical and neutralizing them via their free radical scavenging properties (Lobo et al., 2010). Microbial pigments such as carotenoid, and naphthaquinone demonstrated antioxidant activities (Tuli et al., 2015). Similarly, anthraquinones from the endophytic fungus Stemphylium lycopersici (Li et al., 2017) and melanin from Streptomyces glaucescens NEAE-H (El-Naggar and El-Ewasy, 2017) were reported as antioxidants. Pigment like xanthomonadin showed antioxidant activity and protection against photo damage (Tuli et al., 2015). Similarly, the antioxidant activity of carotenoid pigment from an antarctic bacterium Pedobacter was evaluated. The pigment possessed strong antioxidant capacity and protected the bacterium against oxidative damage (Correa Llanten et al., 2012). The above reports suggest that microbial pigments used as antioxidants may prevent the incidence of many diseases such as cancer and heart disease.

\section{Pigments as Anticancer Agents}

Cancer is one of the most-deadly diseases known to man. The cure for certain types of cancers is considered to be like the Holy Grail since most of the existing treatments are not effective enough to provide full protection (Chakraborty and Rahman, 2012). Efforts to use microbial pigments as anticancer agents have laid the foundation for successful treatments. Many microbial pigments possess anticancer activity. Pigments such as prodigiosin from Pseudoalteromonas sp. 1020R have cytotoxicity against U937 leukemia cells (Wang et al., 2012). Melanin from Streptomyces glaucescens NEAE- $\mathrm{H}$ has been reported for anticancer activity against skin cancer cell line (El-Naggar and El-Ewasy, 2017). Derivatives of anthraquinone from mangrove endophytic fungus Alternaria sp. ZJ9-6B has been reported for anti-cancer activity against human breast cancer cell lines (Huang et al., 2011). Pigments obtained from Monascus spp. showed remarkable anticancer activity against different cancer cells. Pigments from Monascus, such as monascin, showed inhibitory activity against mouse skin carcinogenesis, while ankaflavin showed inhibitory activity against Hep G2 and A549 human cancer cell lines. Similarly, monaphilone A and monaphilone B, exhibits anti-proliferative effect against HEp-2 human laryngeal carcinoma cell lines (Feng et al., 2012). Pigment like prodigiosin has been tested for anticancer activity against more than 60 cancer cell lines and showed a good anticancer activity due to the 
presence of multiple cellular targets (Darshan and Manonmani, 2015). In the view of the above, microbial pigments can be a potential therapeutic agents to treat cancer.

\section{Pigments as Bio-indicators}

Apart from colorants, antioxidants, antimicrobial agents, and anticancer agents, microbial pigments are used as bio-indicators. Fluorescent pigments from bacteria can be used to check the progress of specific reactions. A key example is phycoerythrin, which is used to predict the rate of peroxy radical scavenging in human plasma. The pigment initially shows fluorescence, however, dark spots appear where the pigment reacts with radicals (Delange and Glazer, 1989).

Pigments are used to detect heavy metals for example, Vogesella indigofera produce blue pigment under normal environmental growth condition; however, when exposed to heavy metal like hexavalent chromium, the pigment production did not observed ( $\mathrm{Gu}$ and Cheung, 2001). Microbial pigments can also be used to monitor temperature variation. Pantoea agglomerans produce deep blue pigment only at temperatures of $\geq 10^{\circ} \mathrm{C}$ and hence can be used as temperature indicator for the low-temperature-storage management of foods and clinical materials (Fujikawa and Akimoto, 2011).

\section{CONCLUSION}

Synthetic dyes have caused considerable environmental and health problems. In contrast, microbial pigments are

\section{REFERENCES}

Aberoumand, A. (2011). A review article on edible pigments properties and sources as natural biocolorants in foodstuff and food industry. World J. Dairy Food Sci. $6,71-78$.

Ahmad, W. A., Ahmad, W. Y. M., Zakaria, Z. A., and Yusof, N. Z. (2012). "Application of bacterial pigments as colorant," in Application of Bacterial Pigments as Colorant: the Malaysian Perspective, eds W. A. Ahmad, W. Y. M. Ahmad, Z. A. Zakaria, and N. Z. Yusof (Berlin: Springer), 57-74. doi: 10.1007/ 978-3-642-24520-6_4

Aksu, Z., and Eren, A. T. (2005). Carotenoids production by the yeast Rhodotorula mucilaginosa: use of agricultural wastes as a carbon source. Process Biochem. 40, 2985-2991. doi: 10.1016/j.procbio.2005.01.011

Alihosseini, F., Ju, K. S., Lango, J., Hammock, B. D., and Sun, G. (2008). Antibacterial colorants: characterization of prodiginines and their applications on textile materials. Biotechnol. Prog. 24, 742-747. doi: 10.1021/bp070481r

Alija, A. J., Bresgen, N., Sommerburg, O., Siems, W., and Eckl, P. M. (2004). Cytotoxic and genotoxic effects of $\beta$-carotene breakdown products on primary rat hepatocytes. Carcinogenesis 25, 827-831. doi: 10.1093/carcin/bgh056

Anton, J., Oren, A., Benlloch, S., Rodriguez-Valera, F., Amann, R., and RosselloMora, R. (2002). Salinibacter ruber gen. nov., sp. nov., a novel, extremely halophilic member of the Bacteria from saltern crystallizer ponds. Int. J. Syst. Evol. Microbiol. 52, 485-491. doi: 10.1099/00207713-52-2-485

Aranda, S., Montes-Borrego, M., and Landa, B. B. (2011). Purple-pigmented violacein-producing Duganella spp. inhabit the rhizosphere of wild and cultivated olives in Southern Spain. Microb. Ecol. 62, 446-459. doi: 10.1007/ s00248-011-9840-9

Arcamone, F. M. (1998). From the pigments of the actinomycetes to third generation antitumor anthracyclines. Biochimie 80, 201-206. doi: 10.1016/ S0300-9084(98)80003-5 eco-friendly and used in the textile industry, as food colorants, antioxidants, bio-indicators, and antimicrobial and anticancer agents. Though extensive research has been done to bring microbial pigments from the Petri dish to market, still their output cannot fulfill market demand if synthetic dyes withdrawn. Efforts in finding new microbial sources for pigment production and decrease in production cost through optimization, strain improvement and genetic engineering have to be carried out to eradicate toxic synthetic dyes.

\section{AUTHOR CONTRIBUTIONS}

All authors listed, have made substantial, direct and intellectual contribution to the work, and approved it for publication.

\section{ACKNOWLEDGMENTS}

This work was supported by the Key Project of International Cooperation of Ministry of Science and Technology (MOST) (No. 2013DFA31980), Science and technology infrastructure work project (No. 2015FY110100), and China Postdoctoral Science Foundation Grant No. 2017M612796. W-JL was also supported by Project Supported by Guangdong Province Higher Vocational Colleges and Schools Pearl River Scholar Funded Scheme (2014).

Armstrong, G. A., and Hearst, J. E. (1996). Carotenoids 2: genetics and molecular biology of carotenoid pigment biosynthesis. FASEB J. 10, 228-237.

Arulselvi, I. P., Umamaheswari, S., Sharma, R. G., Kartik, C., and Jayakrishna, C. (2014). Screening of yellow pigment producing bacterial isolates from various eco-climatic areas and analysis of the carotenoid produced by the isolate. J. Food. Process Technol. 5:292. doi: 10.4172/2157-7110. 1000292

Asker, D., Beppu, T., and Ueda, K. (2008). Nubsella zeaxanthinifaciens gen. nov., sp. nov., a zeaxanthin-producing bacterium of the family Sphingobacteriaceae isolated from freshwater. Int. J. Syst. Evol. Microbiol. 58, 601-606. doi: 10.1099/ ijs.0.65493-0

Asker, D., and Ohta, Y. (1999). Production of canthaxanthin by extremely halophilic bacteria. J. Biosci. Bioeng. 88, 617-621. doi: 10.1016/S1389-1723(00) 87089-9

Avalos, J., and Carmen Limon, M. (2015). Biological roles of fungal carotenoids. Curr. Genet. 61, 309-324. doi: 10.1007/s00294-014-0454-x

Babitha, S. (2009). "Microbial pigments," in Biotechnology for Agro-Industrial Residues Utilisation, eds P. Singh-Nee Nigam and A. Pandey (Dordrecht: Springer), 147-162. doi: 10.1007/978-1-4020-9942-7_8

Banerjee, A., Supakar, S., and Banerjee, R. (2014). Melanin from the nitrogenfixing bacterium Azotobacter chroococcum: a spectroscopic characterization. PLoS ONE 9:e84574. doi: 10.1371/journal.pone.0084574

Bartel, P. L., Zhu, C. B., Lampel, J. S., Dosch, D. C., and Connors, N. C. (1990). Biosynthesis of anthraquinones by interspecies cloning of actinorhodin biosynthesis genes in streptomycetes: clarification of actinorhodin gene functions. J. Bacteriol. 172, 4816-4826. doi: 10.1128/jb.172.9.4816-4826. 1990

Berlanga, M., Ruiz, N., Hernandez-Borrell, J., Montero, T., and Vinas, M. (2000). Role of the outer membrane in the accumulation of quinolones by Serratia marcescens. Can. J. Microbiol. 46, 716-722. doi: 10.1139/w00-052 
Bhosale, P., and Bernstein, P. S. (2004). $\beta$-Carotene production by Flavobacterium multivorum in the presence of inorganic salts and urea. J. Ind. Microbiol. Biotechnol. 31, 565-571. doi: 10.1007/s10295-004-0187-9

Błaszczyk, L., Siwulski, M., Sobieralski, K., Lisiecka, J., and Jedryczka, M. (2014). Trichoderma spp. application and prospects for use in organic farming and industry. J. Plant Prot. Res. 54, 309-317. doi: 10.2478/jppr-2014-0047

Blyth, A. W. (1879). The composition of cow's milk in health and disease. J. Chem. Soc. 35:530. doi: 10.1039/CT8793500530

Boger, D. L., and Patel, M. (1987). Total synthesis of prodigiosin. Tetrahedron Lett. 28, 2499-2502. doi: 10.1021/jo00242a013

Boric, M., Danevcic, T., and Stopar, D. (2011). Prodigiosin from Vibrio sp. DSM 14379; a new UV-protective pigment. Microb. Ecol. 62, 528-536. doi: 10.1007/ s00248-011-9857-0

Britton, G. (1995). Structure and properties of carotenoids in relation to function. FASEB J. 9, 1551-1558.

Capon, R. J., Stewart, M., Ratnayake, R., Lacey, E., and Gill, J. H. (2007). Citromycetins and bilains A-C: new aromatic polyketides and diketopiperazines from Australian marine-derived and terrestrial Penicillium spp. J. Nat Prod. 70, 1746-1752. doi: 10.1021/np0702483

Chadni, Z., Rahaman, M. H., Jerin, I., Hoque, K. M. F., and Reza, M. A. (2017). Extraction and optimisation of red pigment production as secondary metabolites from Talaromyces verruculosus and its potential use in textile industries. Mycology 8, 48-57. doi: 10.1080/21501203.2017.1302013

Chakraborty, S., and Rahman, T. (2012). The difficulties in cancer treatment. Ecancermedicalscience. 6:ed16. doi: 10.3332/ecancer.2012.ed16

Chattopadhyay, P., Chatterjee, S., and Sen, S. K. (2008). Biotechnological potential of natural food grade biocolorants. Afr. J. Biotechnol. 7, 2972-2985. doi: 10. 5897/AJB08.433

Chen, D., Han, Y., and Gu, Z. (2006). Application of statistical methodology to the optimization of fermentative medium for carotenoids production by Rhodobacter sphaeroides. Process Biochem. 41, 1773-1778. doi: 10.1016/j. procbio. 2006.03 .023

Conn, H. J., and Jean, E. C. (1941). Value of pigmentation in classifying actinomycetes. J. Bacteriol. 42, 791-799.

Correa Llanten, D. N., Amenabar, M. J., and Blamey, J. M. (2012). Antioxidant capacity of novel pigments from an Antarctic bacterium. J. Microbiol. 50, 374-379. doi: 10.1007/s12275-012-2029-1

Danevcic, T., Boric Vezjak, M., Zorec, M., and Stopar, D. (2016). Prodigiosina multifaceted Escherichia coli antimicrobial agent. PLoS ONE 11:e0162412. doi: 10.1371/journal.pone.0162412

Darshan, N., and Manonmani, H. K. (2015). Prodigiosin and its potential applications. J. Food. Sci. Technol. 52, 5393-5407. doi: 10.1007/s13197-0151740-4

Delange, R. J., and Glazer, A. N. (1989). Phycoerythrin fluorescence-based assay for peroxy radicals: a screen for biologically relevant protective agents. Anal. Biochem. 177, 300-306. doi: 10.1016/0003-2697(89)90056-0

Della Penna, D., and Pogson, B. J. (2006). Vitamin synthesis in plants: tocopherols and carotenoids. Annu. Rev. Plant Biol. 57, 711-738. doi: 10.1146/annurev. arplant.56.032604.144301

Deng, Z. S., Zhao, L. F., Xu, L., Kong, Z. Y., Zhao, P., Qin, W., et al. (2011). Paracoccus sphaerophysae sp. nov., a siderophore-producing, endophytic bacterium isolated from root nodules of Sphaerophysa salsula. Int. J. Syst. Evol. Microbiol. 61, 665-669. doi: 10.1099/ijs.0.021071-0

Dhale, M. A., and Vijay Raj, A. S. (2009). Pigment and amylase production in Penicillium sp NIOM-02 and its radical scavenging activity. Int. J. Food Sci. Technol. 44, 2424-2430. doi: 10.1111/j.1365-2621.2009.01983.x

Dharmaraj, S., Ashokkumar, B., and Dhevendaran, K. (2009). Food-grade pigments from Streptomyces sp. isolated from the marine sponge Callyspongia diffusa. Food. Res. Int. 42, 487-492. doi: 10.1016/j.foodres.2009.02.006

Downham, A., and Collins, P. (2000). Coloring our foods in the last and next millennium. Int. J. Food Sci. Technol. 35, 5-22. doi: 10.1046/j.1365-2621.2000. 00373.x

Dufosse, L. (2006). Microbial production of food grade pigments. Food Technol. Biotechnol. 44, 313-321.

Dufosse, L., Fouillaud, M., Caro, Y., Mapari, S. A., and Sutthiwong, N. (2014). Filamentous fungi are large-scale producers of pigments and colorants for the food industry. Curr. Opin. Biotechnol. 26, 56-61. doi: 10.1016/j.copbio.2013. 09.007
Dufosse, L., Galaup, P., Yaron, A., Arad, S. M., Blanc, P., Murthy, K. N. C., et al. (2005). Microorganisms and microalgae as source of pigments for use: a scientific oddity or an industrial reality? Trends. Food Sci. Technol. 16, 389-406. doi: 10.1016/j.tifs.2005.02.006

Dunlap, C. A., Saunders, L. P., Schisler, D. A., Leathers, T. D., Naeem, N., and Cohan, F. M. (2016). Bacillus nakamurai sp. nov., a black-pigment-producing strain. Int. J. Syst. Evol. Microbiol. 66, 2987-2991. doi: 10.1099/ijsem.0.001135

Duran, N., Justo, G. Z., Ferreira, C. V., Melo, P. S., Cordi, L., and Martins, D. (2007). Violacein: properties and biological activities. Biotechnol. Appl. Biochem. 48, 127-133. doi: 10.1042/BA20070115

El-Bialy, H. A., and Abou El-Nour, S. A. (2015). Physical and chemical stress on Serratia marcescens and studies on prodigiosin pigment production. Ann. Microbiol. 65, 59-68. doi: 10.1007/s13213-014-0837-8

El-Fouly, M. Z., Sharaf, A. M., Shahin, A. A. M., El-Bialy, H. A., and Omara, A. M. A. (2015). Biosynthesis of pyocyanin pigment by Pseudomonas aeruginosa. J. Radiat. Res. Appl. Sci. 8, 36-48. doi: 10.1016/j.jrras.2014.10.007

El-Naggar, N. E., and El-Ewasy, S. M. (2017). Bioproduction, characterization, anticancer and antioxidant activities of extracellular melanin pigment produced by newly isolated microbial cell factories Streptomyces glaucescens NEAE-H. Sci. Rep. 14:42129. doi: 10.1038/srep42129

Fabre, C. E., Santerre, A. L., Loret, M. O., Baberian, R., Pareilleux, A., Goma, G., et al. (1993). Production and food applications of the red pigments of Monascus ruber. J. Food. Sci. 58, 1099-1102. doi: 10.1111/j.1365-2621.1993.tb0 6123.x

Feng, Y., Shao, Y., and Chen, F. (2012). Monascus pigments. Appl. Microbiol. Biotechnol. 96, 1421-1440. doi: 10.1007/s00253-012-4504-3

Feroz, M. S. (2010). Optimization of Riboflavin Production by Fungi on Edible oil Effluent. Master's thesis, Durban University of Technology, Durban.

Franks, A., Haywood, P., Holmstrom, C., Egan, S., Kjelleberg, S., and Kumar, N. (2005). Isolation and structure elucidation of a novel yellow pigment from the marine bacterium Pseudoalteromonas tunicate. Molecules 10, 1286-1291. doi: $10.3390 / 10101286$

Fujikawa, H., and Akimoto, R. (2011). New blue pigment produced by Pantoea agglomerans and its production characteristics at various temperatures. Appl. Environ. Microbiol. 77, 172-178. doi: 10.1128/AEM.00264-10

Gandhi, N. M., Patell, J. R., Gandhi, J., De Souza, N. J., and Kohl, H. (1976). Prodigiosin metabolites of a marine Pseudomonas species. Mar. Biol. 34, 223-227. doi: 10.1007/BF00388799

Garrido-Fernandez, J., Maldonado-Barragan, A., Caballero-Guerrero, B., Hornero-Mendez, D., and Ruiz-Barba, J. L. (2010). Carotenoid production in Lactobacillus plantarum. Int. J. Food. Microbiol. 140, 34-39. doi: 10.1016/j.ijfoodmicro.2010.02.015

Gerber, N. N. (1975). Prodigiosin-like pigments. CRC Crit. Rev. Microbiol. 3, 469-485. doi: 10.3109/10408417509108758

Gokhale, S. B., Tatiya, A. U., Bakliwal, S. R., and Fursule, R. A. (2004). Natural dye yielding plants in India. Nat. prod. Radiance 3, 228-234.

Goodrich, R. P., Edrich, R. A., Li, J., and Seghatchian, J. (2006). The Mirasol PRT system for pathogen reduction of platelets and plasma: an overview of current status and future trends. Transfus. Apher. Sci. 35, 5-17. doi: 10.1016/j.transci. 2006.01.007

Gu, J. D., and Cheung, K. H. (2001). Phenotypic expression of Vogesella indigofera upon exposure to hexavalent chromium, Cr6+. World. J. Microb. Biot. 17, 475-480. doi: 10.1023/A:1011917409139

Gulrajani, M. L. (2001). Present status of natural dyes. Indian J. Fibre Textitle Res. 26, 191-201.

Gupta, C., Amar, P. G., Prakash, D., Goyal, S., and Gupta, S. (2011). Microbes as potential source of biocolors. Pharmacologyonline 2, 1309-1318.

Hajjaj, H., Blanc, P., Groussac, E., Uribelarrea, J. L., Goma, G., and Loubiere, P. (2000). Kinetic analysis of red pigment and citrinin production by Monascus ruber as a function of organic acid accumulation. Enzyme Microb. Technol. 27, 619-625. doi: 10.1016/S0141-0229(00)00260-X

Hakvag, S., Fjaervik, E., Klinkenberg, G., Borgos, S. E. F., Josefsen, K. D., Ellingsen, T. E., et al. (2009). Violacein-producing Collimonas sp. from the sea surface microlayer of costal waters in Trondelag, Norway. Mar. Drugs 7, 576-588. doi: $10.3390 / \mathrm{md} 7040576$

Hamano, P. S., and Kilikian, B. B. (2006). Production of red pigments by Monascus ruber in culture media containing corn steep liquor. Braz. J. Chem. Eng. 23, 443-449. doi: 10.1590/S0104-66322006000400002 
Harris, A. K., Williamson, N. R., Slater, H., Cox, A., Abbasi, S., Foulds, I., et al. (2004). The Serratia gene cluster encoding biosynthesis of the red antibiotic, prodigiosin, shows species and strain-dependent genome context variation. Microbiology 150, 3547-3560. doi: 10.1099/mic.0.27222-0

Hassan, H. M., and Fridovich, I. (1980). Mechanism of the antibiotic action pyocyanine. J. Bacteriol. 141, 156-163.

He, F., Sun, Y. L., Liu, K. S., Zhang, X. Y., Qian, P. Y., Wang, Y. F., et al. (2012). Indole alkaloids from marine-derived fungus Aspergillus sydowii SCSIO 00305. J. Antibiot. 65, 109-111. doi: 10.1038/ja.2011.117

Hill, H. Z. (1992). The function of melanin or six blind people examine an elephant. Bioessays 14, 49-56. doi: 10.1002/bies.950140111

Huang, C. H., Pan, J. H., Chen, B., Yu, M., Huang, H. B., Zhu, X., et al. (2011). Three bianthraquinone derivatives from the mangrove endophytic fungus Alternaria sp. ZJ9-6B from the South China Sea. Mar. Drugs 9, 832-843. doi: 10.3390/ md 9050832

Igarashi, Y., Trujillo, M. E., Martinez-Molina, E., Yanase, S., Miyanaga, S., Obata, T., et al. (2007). Antitumor anthraquinones from an endophytic actinomycete Micromonospora lupini sp. nov. Bioorg. Med. Chem. Lett. 17, 3702-3705. doi: 10.1016/j.bmcl.2007.04.039

Ivanova, E. P., Christen, R., Bizet, C., Clermont, D., Motreff, L., Bouchier, C., et al. (2009). Pseudomonas brassicacearum subsp. neoaurantiaca subsp. nov., orangepigmented bacteria isolated from soil and the rhizosphere of agricultural plants. Int. J. Syst. Evol. Microbiol. 59, 2476-2481. doi: 10.1099/ijs.0.009654-0

Jaswir, I., Noviendri, D., Hasrini, R. F., and Octavianti, F. (2011). Carotenoids: sources, medicinal properties and their application in food and nutraceutical industry. J. Med. Plants Res. 5, 7119-7131. doi: 10.5897/JMPRx11.011

Jayaseelan, S., Ramaswamy, D., and Dharmaraj, S. (2014). Pyocyanin: production, applications, challenges and new insights. World. J. Microbiol. Biotechnol. 30, 1159-1168. doi: 10.1007/s11274-013-1552-5

Kamble, K. D., and Hiwarale, V. D. (2012). Prodigiosin production from Serratia marcescens strains obtained from farm soil. Int. J. Environ. Sci. 3, 631-638. doi: 10.6088/ijes.2012030131061

Kassinger, R. G. (2003). Dyes: From Sea Snails to Synthetics. Minneapolis, MN: Millbrooke Press, Inc.

Kim, D., Lee, J. S., Park, Y. K., Kim, J. F., Jeong, H., Oh, T. K., et al. (2007). Biosynthesis of antibiotic prodiginines in the marine bacterium Hahella chejuensis KCTC 2396. J. Appl. Microbiol. 102, 937-944. doi: 10.1111/j.13652672.2006.03172.x

Kocher, S., and Muller, V. (2011). "The nature and function of carotenoids in the moderately halophilic bacterium Halobacillus halophilus," in Halophiles and Hypersaline Environments, eds A. Ventosa, A. Oren, and Y. Ma (Berlin: Springer), 303-317.

Kramar, A., Llic Tomic, T., Petkovic, M., Radulovic, N., Kostic, M., Jocic, D., et al. (2014). Crude bacterial extracts of two new Streptomyces sp. isolates as bio-colorants for textile dyeing. World. J. Microbiol. Biotechnol. 30, 2231-2240. doi: 10.1007/s11274-014-1644-x

Kuhn, R., Gyorgy, P., and Jauregg, T. W. (1933). Uber eine neue klasse von naturfarbstoffen. Eur. J. Inorg. Chem. 66, 317-320. doi: 10.1002/cber. 19330660244

Kutsal, T., and Ozbas, M. T. (1989). "Microbial production of vitamin B2 (riboflavin)," in Biotechnology of Vitamins, Pigments and Growth Factors, ed. E. J. Vandamme (Dordrecht: Springer), 149-166. doi: 10.1007/978-94-009-11 11-6_10

Langfelder, K., Streibel, M., Jahn, B., Haase, G., and Brakhage, A. A. (2003). Biosynthesis of fungal melanins and their importance for human pathogenic fungi. Fungal Genet. Biol. 38, 143-158. doi: 10.1016/S1087-1845(02)00526-1

Lee, J. H., Kim, Y. S., Choi, T. J., Lee, W. J., and Kim, Y. T. (2004). Paracoccus haeundaensis sp. nov., a Gram-negative, halophilic, astaxanthin-producing bacterium. Int. J. Syst. Evol. Microbiol. 54, 1699-1702. doi: 10.1099/ijs.0.63146-0

Li, D. L., Li, X. M., and Wang, B. G. (2009). Natural anthraquinone derivatives from a marine mangrove plant-derived endophytic fungus Eurotium rubrum: structural elucidation and DPPH radical scavenging activity. J. Microbiol. Biotechnol. 19, 675-680. doi: 10.4014/jmb.0805.342

Li, F., Xue, F., and Yu, X. (2017). GC-MS, FTIR and Raman analysis of antioxidant components of red pigments from Stemphylium lycopersici. Curr. Microbiol. 74, 532-539. doi: 10.1007/s00284-017-1220-3

Li, Y., Li, X., Lee, U., Kang, J. S., Choi, H. D., and Son, B. W. (2006). A new radical scavenging anthracene glycoside, asperflavin ribofuranoside, and polyketides from a marine isolate of the fungus Microsporum. Chem. Pharm. Bull. 54, 882-883. doi: 10.1002/chin.200647202

Lin, Y. B., Wang, X. Y., Fang, H., Ma, Y. N., Tang, J., Tang, M., et al. (2012). Streptomyces shaanxiensis sp. nov., a blue pigment-producing streptomycete from sewage irrigation soil. Int. J. Syst. Evol. Microbiol. 62, 1725-1730. doi: 10.1099/ijs.0.029959-0

Liu, L., Zhou, E. M., Jiao, J. Y., Manikprabhu, D., Ming, H., Huang, M. J., et al. (2015). Hymenobacter mucosus sp. nov., isolated from a soil sample in karst cave. Int. J. Syst. Evol. Microbiol. 65, 4121-4127. doi: 10.1099/ijsem.0.000550

Liu, M., Peng, F., Wang, Y., Zhang, K., Chen, G., and Fang, C. (2009). Kineococcus xinjiangensis sp. nov., isolated from desert sand. Int. J. Syst. Evol. Microbiol. 59, 1090-1093. doi: 10.1099/ijs.0.004168-0

Lobo, V., Patil, A., Phatak, A., and Chandra, N. (2010). Free radicals, antioxidants and functional foods: impact on human health. Pharmacogn. Rev. 4, 118-126. doi: 10.4103/0973-7847.70902

Lu, Y., Wang, L., Xue, Y., Zhang, C., Xing, X. H., Lou, K., et al. (2009). Production of violet pigment by a newly isolated psychrotrophic bacterium from a glacier in Xinjiang, China. Biochem. Eng. J. 43, 135-141. doi: 10.1016/j.bej.2008. 09.009

Malik, K., Tokkas, J., and Goyal, S. (2012). Microbial pigments: a review. Int. J. Microb. Res. Technol. 1, 361-365.

Manachini, P. L., Fortina, M. G., Parini, C., and Craveri, R. (1985). Bacillus thermoruber sp. nov., nom. rev., a red-pigmented thermophilic bacterium. Int. J. Syst. Evol. Microbiol. 35, 493-496. doi: 10.1099/00207713-35-4-493

Manikprabhu, D., and Li, W. J. (2015). “Antimicrobial agents from actinomycetes Chemistry and applications," in Antimicrobials Synthetic and Natural Compounds, eds D. Dhanasekaran, N. Thajuddin, and A. Panneerselvam (Boca Raton, FL: CRC Press), 99-116.

Manikprabhu, D., and Lingappa, K. (2013). $\gamma$ Actinorhodin a natural and attorney source for synthetic dye to detect acid production of fungi. Saudi J. Biol Sci. 20, 163-168. doi: 10.1016/j.sjbs.2013.01.004

Manivasagan, P., Venkatesan, J., Sivakumar, K., and Kim, S. K. (2013). Marine actinobacterial metabolites: current status and future perspectives. Microbiol. Res. 168, 311-332. doi: 10.1016/j.micres.2013.02.002

Mapari, S. A., Meyer, A. S., and Thrane, U. (2009). Photostability of natural orangered and yellow fungal pigments in liquid food model systems. J. Agric. Food. Chem. 57, 6253-6261. doi: 10.1021/jf900113q

Mapari, S. A. S., Thrane, U., and Meyer, A. S. (2010). Fungal polyketide azaphilone pigments as future natural food colorants? Trends Biotechnol. 28, 300-307. doi: 10.1016/j.tibtech.2010.03.004

Marroquin, A. S., and Zapata, M. (1954). Observations on the pigment of Streptomyces coelicolor. Appl. Microbiol. 2, 102-107.

Mata Gomez, L. C., Montanez, J. C., Mendez Zavala, A., and Aguilar, C. N. (2014). Biotechnological production of carotenoids by yeasts: an overview. Microb. Cell Fact. 13:12. doi: 10.1186/1475-2859-13-12

Matz, C., Deines, P., Boenigk, J., Arndt, H., Eberl, L., Kjelleberg, S., et al. (2004). Impact of violacein-producing bacteria on survival and feeding of bacterivorous nanoflagellates. Appl. Environ. Microbiol. 70, 1593-1599. doi: 10.1128/AEM.70. 3.1593-1599.2004

Mavrodi, D. V., Bonsall, R. F., Delaney, S. M., Soule, M. J., Phillips, G., and Thomashow, L. S. (2001). Function analysis of genes for biosynthesis of pyocyanin and phenazine -1-carboxamide from Pseudomonas aeruginosa PAO1. J. Bacteriol. 183, 6454-6465. doi: 10.1128/JB.183.21.6454-6465.2001

McDaniel, R., Ebert-Khosla, S., Hopwood, D. A., and Khosla, C. (1993). Engineered biosynthesis of novel polyketides. Science 262, 1546-1550. doi: 10.1126/science. 8248802

Miao, F. P., Li, X. D., Liu, X. H., Cichewicz, R. H., and Ji, N. Y. (2012). Secondary metabolites from an algicolous Aspergillus versicolor strain. Mar Drugs 10, 131-139. doi: 10.3390/md10010131

Mondal, S. K., Samantaray, D. P., and Mishra, B. B. (2015). Optimization of pigment production by a novel Bacillus sp. BBMRH isolated from cow dung. J. Pure Appl. Microbiol. 9, 2321-2326.

Nagia, F. A., and El-Mohamedy, R. S. R. (2007). Dyeing of wool with natural anthraquinone dyes from Fusarium oxysporum. Dyes Pigments 75, 550-555. doi: 10.1016/j.dyepig.2006.07.002

Nakamura, Y., Asada, C., and Sawada, T. (2003). Production of antibacterial violet pigment by psychrotropic bacterium RT102 strain. Biotechnol. Bioprocess Eng. 8, 37-40. doi: 10.1007/BF02932896 
Norman, R. S., Moeller, P., Mc Donald, T. J., and Morris, P. J. (2004). Effect of pyocyanin on a crude oil degrading microbial community. Appl. Environ. Microbiol. 70, 4004-4011. doi: 10.1128/AEM.70.7.4004-4011.2004

Ogugbue, C. J., and Sawidis, T. (2011). Bioremediation and detoxification of synthetic wastewater containing triarylmethane dyes by Aeromonas hydrophila isolated from industrial effluent. Biotechnol. Res. Int. 2011:967925. doi: 10.4061/ 2011/967925

Ordenes Aenishanslins, N., Anziani-Ostuni, G., Vargas-Reyes, M., Alarcon, J., Tello, A., and Perez-Donoso, J. M. (2016). Pigments from UV-resistant antarctic bacteria as photosensitizers in dye sensitized solar cells. J. Photochem. Photobiol. B. 162, 707-714. doi: 10.1016/j.jphotobiol.2016.08.004

Panesar, R., Kaur, S., and Panesar, P. S. (2015). Production of microbial pigments utilizing agro-industrial waste: a review. Curr. Opin. Food. Sci. 1, 70-76. doi: $10.1016 /$ j.cofs.2014.12.002

Peix, A., Berge, O., Rivas, R., Abril, A., and Velazquez, E. (2005). Pseudomonas argentinensis sp. nov., a novel yellow pigment-producing bacterial species, isolated from rhizospheric soil in Cordoba, Argentina. Int. J. Syst. Evol. Microbiol. 55, 1107-1112. doi: 10.1099/ijs.0.63445-0

Petinate, S. D., Martins, R. M., Coelho, R. R., Meirelles, M. N., Branquinha, M. H., and Vermelho, A. B. (1999). Influence of growth medium in proteinase and pigment production by Streptomyces cyaneus. Mem. Inst. Oswaldo Cruz 94, 173-177. doi: 10.1590/S0074-02761999000200008

Plonka, P. M., and Grabacka, M. (2006). Melanin synthesis in microorganismsbiotechnological and medical aspects. Acta. Biochim. Pol. 53, 429-443.

Poorniammal, R., and Gunasekaran, S. (2015). Physical and chemical stability analysis of Thermomyces yellow pigment for food application. Int. J. Food. Ferment. Technol. 5, 47-52. doi: 10.5958/2277-9396.2015.00006.9

Poorniammal, R., Parthiban, M., Gunasekaran, S., Murugesan, R., and Thilagavathy, R. (2013). Natural dye production from Thermomyces sp. fungi for textile application. Indian J. Fiber Textile Res. 38, 276-279.

Priess, K., Le Campion-Alsumard, T., Golubic, S., Gadel, F., and Thomassin, B. A. (2000). Fungi in corals: black bands and density-banding of Porites lutea and P. lobata skeleton. Mar. Biol. 136, 19-27. doi: 10.1007/s002270050003

Ramaprasad, E. V., Bharti, D., Sasikala, C. H., and Ramana, C. H. V. (2015). Zooshikella marina sp. nov. a cycloprodigiosin- and prodigiosin-producing marine bacterium isolated from beach sand. Int. J. Syst. Evol. Microbiol. 65, 4669-4673. doi: 10.1099/ijsem.0.000630

Rana, S., and Salam, M. D. (2014). Antimicrobial potential of actinomycetes isolated from soil samples of Punjab, India. J. Microbiol. Exp. 1:00010. doi: 10.15406/jmen.2014.01.00010

Rankovic, B. R., Kosanic, M. M., and Stanojkovic, T. P. (2011). Antioxidant, antimicrobial and anticancer activity of the lichens Cladonia furcata, Lecanora atra and Lecanora muralis. BMC. Complement. Altern. Med. 11:97. doi: 10.1186/ 1472-6882-11-97

Rymbai, H., Sharma, R. R., and Manish, S. (2011). Biocolorants and its implications in Health and Food Industry - a review. Int. J. PharmTech Res. 3, 2228-2244.

Sasidharan, A., Sasidharan, N. K., Amma, D. B., Vasu, R. K., Nataraja, A. V., and Bhaskaran, K. (2015). Antifungal activity of violacein purified from a novel strain of Chromobacterium sp. NIIST (MTCC 5522). J. Microbiol. 53, 694-701. doi: 10.1007/s12275-015-5173-6

Selvameenal, L., Radhakrishnan, M., and Balagurunathan, R. (2009). Antibiotic pigment from desert soil actinomycetes; biological activity, purification and chemical screening. Indian J. Pharm Sci. 71, 499-504. doi: 10.4103/0250-474X. 58174

Shirata, A., Tsukamoto, T., Yasui, H., Hayasaka, T., Hayasaka, S., Kojima, A., et al. (2000). Isolation of bacteria producing bluish-purple pigment and use for dyeing. Japan Agric. Res. Q. 34, 131-140.

Silva, C., Cabral, J. M. S., and Keulen, F. V. (2004). Isolation of a $\beta$-total carotenoids over-producing soil bacterium, Sphingomonas sp. Biotechnol. Lett. 26, 257-262. doi: 10.1023/B:BILE.0000013716.20116.dc

Silveira, S. T., Daroit, D. J., and Brandelli, A. (2008). Pigment production by Monascus purpureus in grape waste using factorial design. LWT Food Sci. Technol. 41, 170-174. doi: 10.1016/j.lwt.2007.01.013

Smetanina, O. F., Kalinovskii, A. I., Khudyakova, Y. V., Slinkina, N. N., Pivkin, M. V., and Kuznetsova, T. A. (2007). Metabolites from the marine fungus Eurotium repens. Chem. Nat. Compd. 43, 395-398. doi: 10.1007/s10600-007$0147-5$
Soliev, A. B., Hosokawa, K., and Enomoto, K. (2011). Bioactive pigments from marine bacteria: applications and physiological roles. Evid. Based Complement. Alternat. Med. 2011:670349. doi: 10.1155/2011/670349

Sudha Gupta, C., and Aggarwal, S. (2016). Dyeing wet blue goat nappa skin with a microbial colorant obtained from Penicillium minioluteum. J. Clean. Prod. 127, 585-590. doi: 10.1016/j.jclepro.2016.03.043

Surwase, S. N., Jadhav, S. B., Phugare, S. S., and Jadhav, J. P. (2013). Optimization of melanin production by Brevundimonas sp. SGJ using response surface methodology. 3 Biotech 3, 187-194. doi: 10.1007/s13205-012-0082-4

Tao, J., Wang, X., Shen, Y., and Wei, D. (2005). Strategy for the improvement of prodigiosin production by a Serratia marcescens mutant through fed-batch fermentation. World J. Microbiol. Biotechnol. 21, 969-972. doi: 10.1007/s11274004-7257-z

Tuli, H. S., Chaudhary, P., Beniwal, V., and Sharma, A. K. (2015). Microbial pigments as natural color sources: current trends and future perspectives. J. Food. Sci. Technol. 52, 4669-4678. doi: 10.1007/s13197-014-1601-6

Umadevi, K., and Krishnaveni, M. (2013). Antibacterial activity of pigment produced from Micrococcus luteus KF532949. Int. J. Chem. Anal. Sci. 4, 149-152. doi: 10.1016/j.ijcas.2013.08.008

Velmurugan, P., Kim, M. J., Park, J. S., Karthikeyan, K., Lakshmanaperumalsamy, P., Lee, K. J., et al. (2010). Dyeing of cotton yarn with five water soluble fungal pigments obtained from five fungi. Fiber Polym. 11, 598-605. doi: 10.1007/s12221-010-0598-5

Vendruscolo, F., Tosin, I., Giachini, A. J., Schmidell, W., and Ninow, J. L. (2014). Antimicrobial activity of Monascus pigments produced in submerged fermentation. J. Food Process Preserv. 38, 1860-1865. doi: 10.1111/jfpp.12157

Venil, C. K., Aruldass, C. A., Dufosse, L., Zakaria, Z. A., and Ahmad, W. A. (2014). Current perspective on bacterial pigments: emerging sustainable compounds with coloring and biological properties for the industry-an incisive evaluation. RSC Adv. 4, 39523-39529. doi: 10.1039/c4ra06162d

Venil, C. K., Zakaria, Z. A., and Ahmad, W. A. (2013). Bacterial pigments and their applications. Process Biochem. 48, 1065-1079. doi: 10.1016/j.procbio.2013. 06.006

Visalakchi, S., and Muthumary, J. (2010). Antimicrobial activity of the new endophytic Monodictys castaneae SVJM139 pigment and its optimization. Afr. J. Microbiol. Res. 4, 38-44.

Wackenroder, H. (1831). Ueber das Oleum radicis Dauci aetherum, das Carotin, den Carotenzucker und den officinellen succus Dauci; so wie auch über das Mannit, welches in dem Möhrensafte durch eine besondere Art der Gahrung gebildet wird. Geigers Magazin Pharmazie. 33, 144-172.

Walford, J. (ed.). (1980). "Historical development of food colouration," in Developments in Food Colours, (London: Applied Science publishers).

Wang, H., Jiang, P., Lu, Y., Ruan, Z., Jiang, R., Xing, X. H., et al. (2009). Optimization of culture conditions for violacein production by a new strain of Duganella sp. B2. Biochem. Eng. J. 44, 119-124. doi: 10.1016/j.bej.2008.11.008

Wang, Y., Nakajima, A., Hosokawa, K., Soliev, A. B., Osaka, I., Arakawa, R., et al. (2012). Cytotoxic prodigiosin family pigments from Pseudoalteromonas sp. 1020R isolated from the Pacific coast of Japan. Biosci. Biotechnol. Biochem. 76, 1229-1232. doi: 10.1271/bbb.110984

Xia, X. K., Huang, H. R., She, Z. G., Shao, C. L., Liu, F., Cai, X. L., et al. (2007). $1 \mathrm{H}$ and $13 \mathrm{C}$ NMR assignments for five anthraquinones from the mangrove endophytic fungus Halorosellinia sp. (No. 1403). Magn. Reson. Chem. 45, 1006-1009. doi: $10.1002 / \mathrm{mrc} .2078$

Yada, S., Wang, Y., Zou, Y., Nagasaki, K., Hosokawa, K., Osaka, I., et al. (2008). Isolation and characterization of two groups of novel marine bacteria producing violacein. Mar. Biotechnol. 10, 128-132. doi: 10.1007/s10126-007-9046-9

Yang, L. H., Xiong, H., Lee, O. O., Qi, S. H., and Qian, P. Y. (2007). Effect of agitation on violacein production in Pseudoalteromonas luteoviolacea isolated from a marine sponge. Lett. Appl. Microbiol. 44, 625-630. doi: 10.1111/j.1472765X.2007.02125.X

Yi, H., Chang, Y. H., Oh, H. W., Bae, K. S., and Chun, J. (2003). Zooshikella ganghwensis gen. nov., sp. nov., isolated from tidal flat sediments. Int. J. Syst. Evol. Microbiol. 53, 1013-1018. doi: 10.1099/ijs.0.02521-0

Yusof, N. Z. (2008). Isolation and Applications of Red Pigment from Serratia marcescens. B.Sc. thesis, Universiti Teknologi Malaysia, Johor Bahru.

Zheng, L., Cai, Y., Zhou, L., Huang, P., Ren, X., Zuo, A., et al. (2017). Benzoquinone from Fusarium pigment inhibits the proliferation of estrogen receptor-positive 
MCF-7 cells through the NF-кB pathway via estrogen receptor signaling. Int. J. Mol. Med. 39, 39-46. doi: 10.3892/ijmm.2016.2811

Zhu, H. H., Guo, J., Yao, Q., Yang, S. Z., Deng, M. R., and Li, T. H. (2011). Streptomyces caeruleatus sp. nov., with dark blue diffusible pigment. Int. J. Syst. Evol. Microbiol. 61, 507-511. doi: 10.1099/ijs.0.017 392-0

Zhu, H. H., Guo, J., Yao, Q., Yang, S. Z., Deng, M. R., Phuong le, T. B., et al. (2007). Streptomyces vietnamensis sp. nov., a streptomycete with violet blue diffusible pigment isolated from soil in Vietnam. Int. J. Syst. Evol. Microbiol. 57, 1770-1774. doi: 10.1099/ijs.0.64774-0
Conflict of Interest Statement: The authors declare that the research was conducted in the absence of any commercial or financial relationships that could be construed as a potential conflict of interest.

Copyright $\odot 2017$ Narsing Rao, Xiao and Li. This is an open-access article distributed under the terms of the Creative Commons Attribution License (CC BY). The use, distribution or reproduction in other forums is permitted, provided the original author(s) or licensor are credited and that the original publication in this journal is cited, in accordance with accepted academic practice. No use, distribution or reproduction is permitted which does not comply with these terms. 